\title{
The Effect of Acute and Chronic Infection-Induced by AvrAProtein of Salmonella typhimurium on Radical Oxygen Species, Phosphatase and Tensin Homolog, and Cellular Homolog Expression During the Development of Colon Cancer
}

\begin{abstract}
Satuman Satuman ${ }^{1,2}$, Desi Sandra Sari ${ }^{3}$, Eva Rachmi $^{4}$, Eddy Herman Tanggo ${ }^{5}$, Hari Basuki Notobroto ${ }^{6}$, Ketut Sudiana ${ }^{7}$ Sofia Mubarika ${ }^{8}$, Fedik Abdul Rantam ${ }^{9,10}$, Soemarno Soemarno ${ }^{11}$, Eddy Bagus Warsito ${ }^{12 *}$

${ }^{1}$ Doctoral Student of Medical Science, Faculty of Medicine, Universitas Airlangga, Surabaya, Indonesia; ${ }^{2}$ Laboratory of Human Physiology, Faculty of Medicine, Universitas Brawijaya, Malang, Indonesia; ${ }^{3}$ Department of Periodontal, Faculty of Dentistry, Universitas Jember, Jember Regency, Indonesia; ${ }^{4}$ Laboratory of Anatomy, Faculty of Medicine, Universitas Mulawarman, Samarinda, Indonesia; ${ }^{5}$ Departement of Oncology, Faculty of Medicine, Universitas Airlangga, Surabaya, Indonesia; ${ }^{6}$ Department of Biostatistics and Population Studies Statistic, Faculty of Public Health, Universitas Airlangga, Surabaya, Indonesia; ${ }^{7}$ Department of Pathology Anatomy, Faculty of Medicine, Universitas Airlangga, Surabaya, Indonesia; ${ }^{8}$ Department of Anatomy and Histology, Faculty of Medicine, Universitas Gadjah Mada, Yogyakarta, Indonesia; ${ }^{9}$ Stem Cells Research and Development Center, Universitas Airlangga, Surabaya, Indonesia; ${ }^{10}$ Department of Virology, Microbiology, and Immunology, Faculty of Veterinary Medicine, Universitas Airlangga, Surabaya, Indonesia; ${ }^{11}$ Department of Microbiology, Faculty of Medicine, Universitas Brawijaya, Malang, Indonesia; ${ }^{12}$ Department of Microbiology, Faculty of Medicine, Universitas Airlangga, Surabaya, Indonesia
\end{abstract}

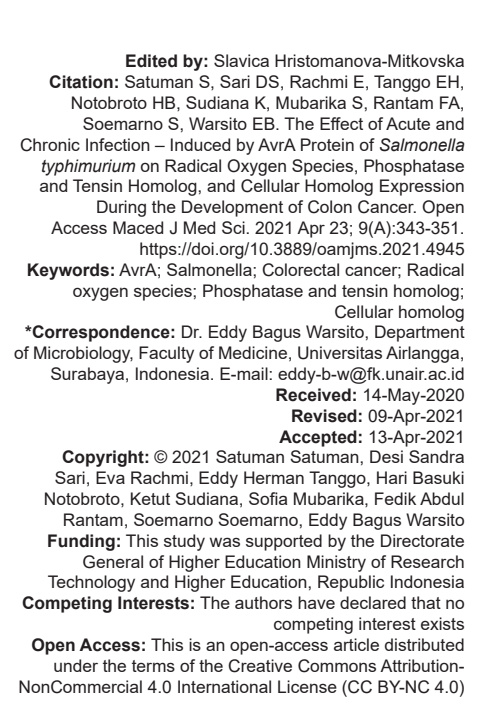

\section{Abstract}

AIM: The study aimed to analyze the effect of AvrA effector protein of Salmonella typhimurium in inducing colon cancer through increased of radical oxygen species (ROS), phosphatase and tensin homolog (PTEN), and avian myelocytomatosis virus oncogene cellular homolog (c-Myc) expression, in mice model of colorectal cancer.

METHODS: This study used Balb/c mice which were divided into four types of groups: Negative control, exposed to azoxymethane (AOM), treatment with $\mathrm{AOM}$, and AvrA (AOM+AvrA), and treatment with AOM and S. typhimurium $(\mathrm{AOM}+\mathrm{S}$. typhimurium). Each type consists of a 1-week treatment group and a 12-weeks treatment group, with a final number of eight groups. S. typhimurium-specific protein (AvrA) was isolated and then injected to AOM + AvrA groups $(40 \mu \mathrm{g} / 50 \mu \mathrm{l})$, intraperitoneally. S. typhimurium was administered orally to AOM + S. typhimurium groups. ROS production in peripheral blood mononuclear cells was measured by flow cytometry. PTEN and c-Myc expression in colon tissue were detected through immunohistochemistry.

RESULTS: The study showed that ROS production was higher in the 12-week $A O M+S$. typhimurium treatment group compared with other 12-week treatment groups $(p<0.05)$. AOM + AvrA and AOM $+S$. typhimurium groups demonstrated a decrease of PTEN expression and an increase of $c-M y c$ expression in colon tissue, compared to AOM groups, both in 1-week and 12-weeks treatment $(p<0.05)$.

CONCLUSION: AvrA effector protein from S. typhimurium increased ROS production and c-Myc expression while suppressed PTEN expression as markers of colorectal cancer, both in acute and chronic infections.

\section{Introduction}

Colorectal cancer is a major contributor to morbidity and death in the world. The incidence of colorectal cancer is the third-highest in the world and the second most deadly after lung cancer. In 2018 , there were an estimated 1,006,019 men and 794,958 women living with colorectal cancer in the world [1]. Colorectal cancer is triggered by several factors including carcinogenic chemicals, ultraviolet light, viruses, and bacteria facilitating gene mutations [2].
An increased risk of colorectal cancer was found among patients diagnosed with severe salmonellosis [3]. Salmonella has several T3SS organelles such as SopE, SptP, SopB, SipA, and SipC, which contribute to its pathogenicity. AvrA is another Salmonella effector protein that has not been widely known. The function of AvrA is presumed to be the same as other effector proteins [4]. The mechanism of AvrA effector in the pathogenesis of Salmonellosis remains not clearly understood. Early-stage of Salmonella infection is characterized by activation of macrophages, inflammation of infected tissue, and production of 
gamma interferon (IFN) by several cells. T CD4 ${ }^{+}$ cells play an important role in controlling Salmonella infections, together with $\mathrm{CD}^{+}$and $\mathrm{T} \gamma \delta$ cells [5].

The increased immune system activity stimulates cytokine synthesis [6], which, in turn, triggers both chronic inflammation and radical oxygen species (ROS) production. Uncontrollable inflammation and ROS in host cells ultimately damage the tissue occupied by Salmonella during the infection [7]. Salmonella or its effector proteins induce inflammation and ROS by activating the JAK-STAT, JNK, and Wnt pathways in stem cells. Activated pathways cause uncontrolled cell cycles which lead to increased risk of malignancy. Cancer stem cells will stick (homing) on enterocytes because of chemoattractants produced by the inflammation process. Effector proteins of Salmonella activate TollLike receptor-4 therefore it blocks phosphatase and tensin homolog (PTEN) and stimulates MyD88. The activation of both proteins, followed by phosphorylation of $\mathrm{NF}-\mathrm{kB}$, leads to nuclear translocation of NFkB subunits to stimulate protein synthesis. Some of the synthesized proteins are proteins involving in the proliferation (cellular homolog [c-Myc], and cyclinD1), apoptosis (FasL, BAX, and Caspase), and angiogenesis (VEGF and c-IAP2) [8]. The study explored the effect of AvrA's effector on ROS production in peripheral blood mononuclear cell (PBMC) as inflammation indicator, and PTEN and c-Myc expression in colon tissue as colon cancer markers. AvrA protein used for this study was isolated from Salmonella typhimurium as the best-studied serovar of Salmonellosis.

\section{Materials and Methods}

\section{Ethics statement}

This study was approved by the Research Ethics Commission of the Faculty of Medicine, Universitas Brawijaya, Indonesia, as stated in the Code of Ethics for Research, number 154/EC/KEPK$53 / 05 / 2019$. All efforts were made to minimize suffering.

\section{S. typhimurium culture}

S. typhimurium was obtained from American Type Cell Culture with Catalog Number 2354 Lot Number \# 58105535. Bacteria isolates were propagated on MacConkey medium and then incubated at $37^{\circ} \mathrm{C}$ temperature for 18-24 $\mathrm{h}$. The culture from the MacConkey medium was transferred to a biphasic medium consisting of $\mathrm{BHI}$ liquid medium and TCG agar slant medium. The culture was incubated at $37^{\circ} \mathrm{C}$ temperature for $24 \mathrm{~h}$.

\section{Isolation of S. typhimurium bacterial protein}

After S. typhimurium had been cultured, centrifugation was carried out to separate bacteria from the media. The media were removed and the cell resuspended with phosphate buffer saline (PBS). This step was repeated 3 times. The last precipitate was resuspended with TRIZol reagent to isolate bacterial proteins. The AvrA protein was identified as the presence of $34 \mathrm{kDa}$ protein, detected by mouse anti-AvrA polyclonal antibody (Abcam, USA), through Western blotting.

The bands corresponding to the proteins were excised from the gels and transferred to a cellophane membrane. The gel solution was electro-eluted with Horizontal Electrophoresis Apparatus for $25 \mathrm{~min}$. The results were dialyzed with a sterile PBS for $2 \times 24 \mathrm{~h}$. The concentration of the isolated protein was calculated with nanodrop.

\section{Animal groups}

The experiment was performed using male Balb/c mice (Pusvetma, Indonesia) that were 3 weeks old and had $\pm 50 \mathrm{~g}$ body weight. The animal randomly assigned to four treatment groups: The negative control group which was not exposed, the positive control group which was only exposed to azoxymethane (AOM), the group exposed to AOM + AvrA, and the group exposed to $\mathrm{AOM}$ and $\mathrm{S}$. typhimurium (AOM + S. typhimurium). Each group was divided into subgroups: A 1-week and a 12 weeks duration of treatment. The 1-week duration treatment depicted acute inflammatory mice model while the 12-week duration treatment depicted chronic inflammatory mice model [4].

\section{Salmonella or AvrA-infected colorectal cancer mouse model}

A series of treatments were given regularly every week. Thus, the number of treatment series was proportional to the duration of the treatment, whether 1 week or 12 weeks. Mice have fasted for $4 \mathrm{~h}$. Afterward, the mice were given $7.5 \mathrm{mg} /$ mouse streptomycin (100 $\mu$ l sterile solution) and continued with water and food supply ad libitum. Exposures were conducted $20-h$ after streptomycin treatment, with preceded $4 \mathrm{~h}$ fasting. AvrA protein exposure was given to AOM + AvrA group, intraperitoneally $(40 \mu \mathrm{g} / 50 \mathrm{ml})$. S. typhimurium was given orally to AOM + S. typhi group, as $100 \mu \mathrm{l}$ suspension of $1 \times 10^{6} \mathrm{CFU}$ in Hank's balanced salt solution. Both the negative control group and the AOM group were treated with sterile Hank's balanced salt solution, orally. AOM (TCl, Tokyo) was given through oral gavage to all groups (10 $\mathrm{mg} / \mathrm{ml})$, except for the negative control group.

\section{Measurement of colon cancer antigen (CCA)}

Before the main experiment, we explored the effects of AOM, S. typhimurium, and AvrA on 
colon carcinogenesis, using four groups of mice given the same type of exposures with the main experiment. Blood samples were collected on the $14^{\text {th }}$ day of treatments. Mouse CCA was detected using Sandwich- enzyme-linked immunosorbent assay (ELISA) kit (Elisa Genie, UK). The serum was added to CCAs-antibody coated wells. Then biotinylated detection antibody specific for Mouse CCA and Avidin-Horseradish Peroxidase conjugate was added to each well successively and incubated. The substrate solution was added to each well. The enzyme-substrate reaction was terminated by adding Stop Solution and the color turns yellow. The optical density was measured spectrophotometrically at $450 \mathrm{~nm}$.

\section{Measurement of PBMC intracellular ROS}

Intracellular ROS production was measured in PBMC. The cells were washed twice with PBS before being shaken slowly. The final precipitate was added with $100 \mu \mathrm{L}$ PBS and $1 \mu \mathrm{M}$ carboxy-H2DCFDA (TRC, Canada). The cells were incubated in dark conditions for $60 \mathrm{~min}$ at room temperature. ROS testing was analyzed with flow cytometry (FACS Calibur, BD) on the FL1 channel [9].

\section{PTEN-1 and c-Myc expression in colon \\ tissue}

The expression of PTEN and c-Myc was observed in the colon tissue slides by immunohistochemical staining. Each protein expression was detected using mouse anti-PTEN monoclonal antibody or mouse anti-c-Myc monoclonal antibody (IGEIA, Indonesia) in fetal bovine serum (1:100). Their expression appeared as brown precipitates in the colonic crypt regions [10], [11]. The expression was analyzed using ImmunoRatio $®$ software. The results were presented as the percentage of positively-stained areas out of the total nuclear area.

\section{Data analysis}

The statistical analysis was performed with SPSS 23. Kruskal-Wallis (non-normal distribution) or one-way ANOVA (normal distribution) tests were applied to compare variables within the same duration. A comparison of each treatment group between different duration was using Mann-Whitney test (non-normal distribution) or independent t-test (normal distribution). Further comparisons between all groups were utilizing Kruskal-Wallis or one-way ANOVA continued with post hoc multiple comparisons LSD. $p<0.05$ was accepted as statistically significant.

\section{Results}

\section{CCA level in plasma}

CCA concentration in plasma was detected higher in AOM exposure than in negative controls. Exposure to AvrA and S. typhimurium increases CCA higher than the AOM group. The highest plasma CCA levels detected in AOM + S. typhimurium group, despite not significantly different than the AOM + AvrA group (Figure 1).

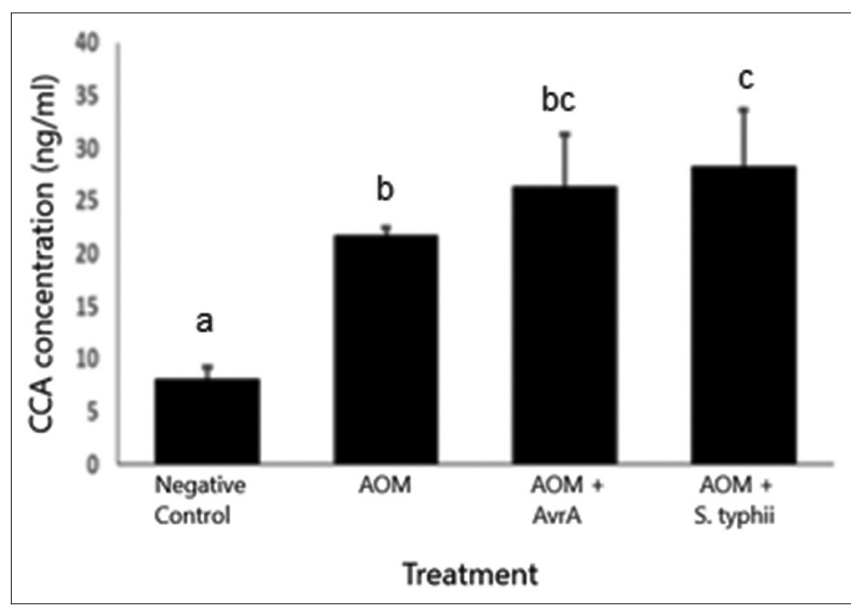

Figure 1: The results of measurements of plasma colon cancer antigen (CCA) levels after 2-weeks treatments. CCA level exploration was done before the main experiment $a, b$, or $c$ labels indicate that there was no significant difference between groups with the same label, as tested by multiple comparisons $L S D$

\section{ROS production in the PBMC of colorectal cancer model mouse}

Compared with the negative control group, AOM treatment in the AOM group induced a significant increase in ROS production after a week, but there was no difference at 12 weeks of treatment duration (Figure 2). Neither the AOM + AvrA nor AOM + $S$. typhimurium group experienced a significant change in ROS production compared to the AOM group at 1-week treatment. After 12 weeks of treatment, ROS production was induced higher in the AOM + AvrA group compared to the AOM group, and the highest in the $\mathrm{AOM}+\mathrm{S}$. typhimurium group (Figure 3). ROS production in the $\mathrm{AOM}+S$. typhimurium group almost doubled at 12 weeks compared to 1 -week treatment (Table 1).

Table 1: Percentage of ROS production in PBMC of 1-week and 12 weeks treatment groups

\begin{tabular}{llll}
\hline Treatment & \multicolumn{2}{l}{ Weeks } & $\mathrm{p}$ \\
\cline { 2 - 3 } & 1 & 12 & \\
\hline Negative control & $13.22 \pm 8.52$ & $4.86 \pm 2.30$ & $0.251^{* * *}$ \\
AOM & $23.32 \pm 1.87$ & $3.51 \pm 0.61$ & $0.000^{* *}$ \\
AOM+AvrA & $21.19 \pm 8.30$ & $24.76 \pm 4.71$ & $0.754^{* * *}$ \\
AOM+S. typhimurium & $23.12 \pm 2.86$ & $45.78 \pm 2.93$ & $0.000^{* *}$ \\
p & $0.052^{*}$ & $0.001^{*}$ & $0.000^{*}$ \\
\hline Data were represented as Mean \pm SEM. & ${ }^{*}$ Kruskal-Wallis test, ${ }^{* *}$ Independent t-test, ${ }^{* * *}$ Mann-Whitney \\
test. Salmonella typhimurium: $S$. . typhimurium, ROS: Radical oxygen species, AOM: Azoxymethane, \\
PBMC: Peripheral blood mononuclear cell.
\end{tabular}




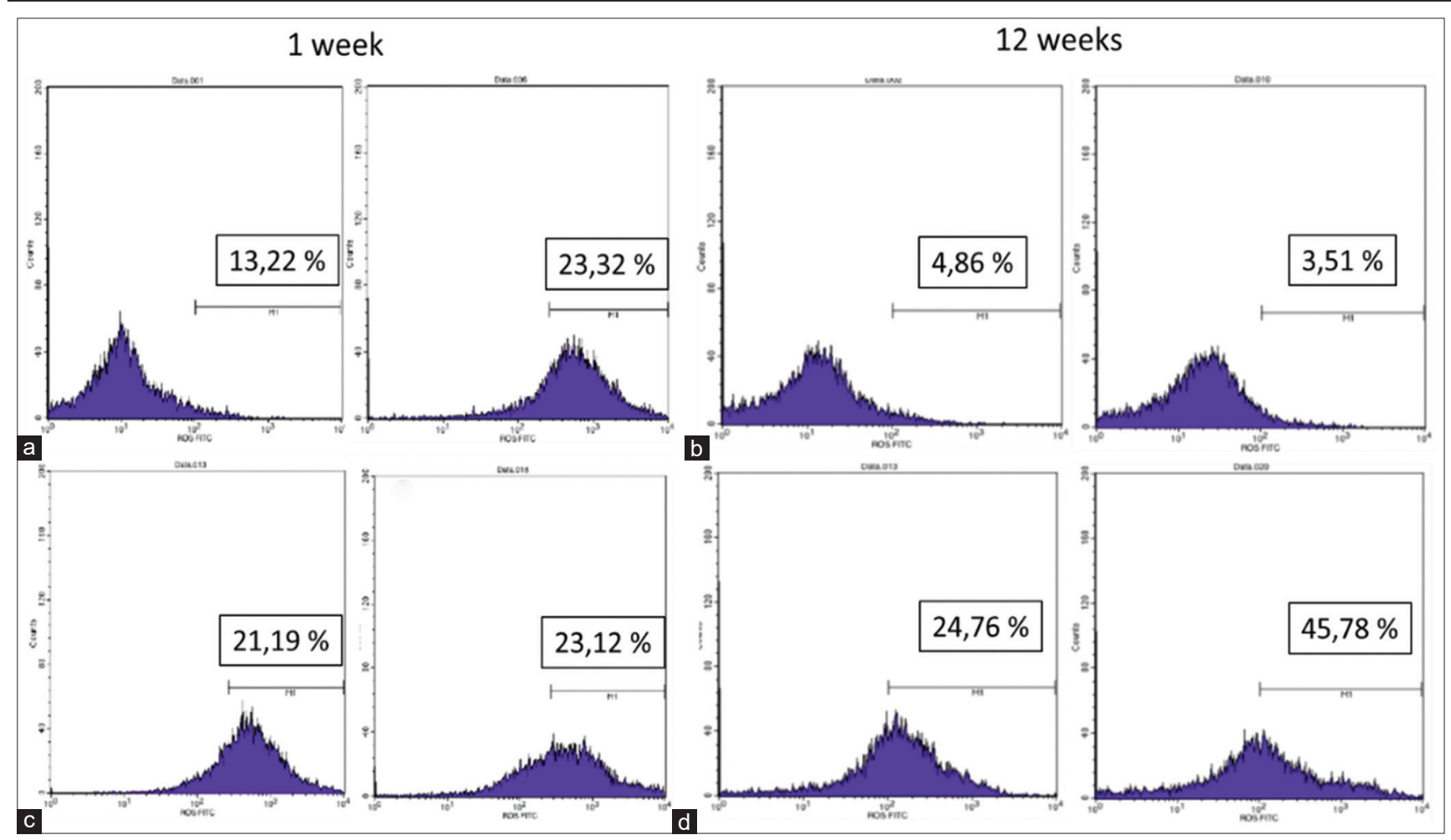

Figure 2: The results of radical oxygen species flow cytometry among the study groups. (a) Negative control; (b) azoxymethane (AOM); (c) $A O M+$ AvrA and (d) $A O M+$ Salmonella typhimurium

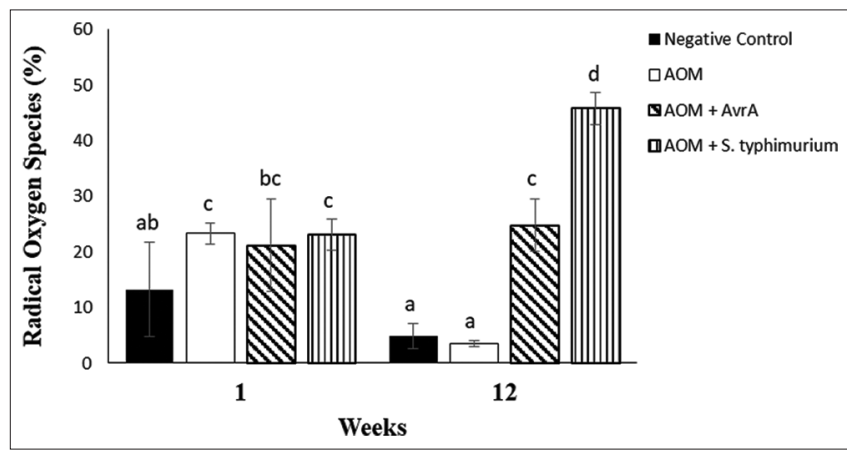

Figure 3: Comparison of radical oxygen species production between study groups $a, b, c$, or d labels indicates that there was no significant difference between groups with the same label, as tested by the Mann-Whitney test

\section{PTEN expression in the colon tissue of} colorectal cancer model mouse

AOM significantly increases PTEN expression in both 1-week and 12 weeks of treatment. The administration of AvrA or S. typhimurium attenuated PTEN expression compared to the AOM group in both treatment durations (Figure 4). The reduction of PTEN expression in the AOM + S. typhimurium group was lower than in the AOM + AvrA group. Compared to 1-week treatment, a longer duration of 12 weeks elevated PTEN expression on AOM + AvrA and AOM + S.typhi groups (Table 2). Nevertheless, the expression of PTEN in these two groups was still lower than the AOM group for the same treatment duration (Figure 5).
Table 2: PTEN expression of the colon tissue of colorectal cancer model mouse treated with AvrA

\begin{tabular}{llll}
\hline Treatment & \multicolumn{2}{l}{ Weeks } & $\mathrm{p}$ \\
\cline { 2 - 3 } & 1 & 12 & $0.487^{* *}$ \\
\hline Negative Control & $22.98 \pm 8.57$ & $26.75 \pm 7.73$ & $0.046^{\star *}$ \\
AOM & $85.52 \pm 5.43$ & $74.62 \pm 8.78$ & $0.031^{* *}$ \\
AOM+AvrA & $52.42 \pm 7.59$ & $62.48 \pm 4.03$ & $0.001^{* *}$ \\
AOM+S. typhimurium & $38.88 \pm 2.54$ & $49.53 \pm 3.98$ & $0.000^{*}$ \\
p & $0.000^{*}$ & $0.000^{*}$ & ${ }^{*}$ \\
\hline Data were represented as Mean \pm SEM. ${ }^{*}$ One-way ANOVA test, ${ }^{* *}$ Independent t-test. & Salmonella \\
typhimurium: S. typhimurium, PTEN: Phosphatase and tensin homolog, AOM: Azoxymethane.
\end{tabular}

\section{c-Myc expression in the colon tissue of} colorectal cancer model mouse

AOM exposure increased c-Myc expression in AOM groups compared to negative controls at 1-week and 12 weeks of treatment (Table 3). c-Myc expression in the $\mathrm{AOM}+\mathrm{AvrA}$ and $\mathrm{AOM}+\mathrm{S}$. typhimurium groups had increased compared to the AOM group in both treatment durations. After 1-week treatment, AvrA administration increased c-Myc expression higher than the $S$. typhimurium administration. But at 12 weeks' duration, the rise in c-Myc expression in both groups

Table 3: The expression of c-Myc of the colon of male mice treated AvrA S. typhimurium for 1 and 12 weeks

\begin{tabular}{|c|c|c|c|}
\hline \multirow[t]{2}{*}{ Treatment } & \multicolumn{2}{|l|}{ Weeks } & \multirow[t]{2}{*}{$p$} \\
\hline & 1 & 12 & \\
\hline Negative control & $35.12 \pm 3.31$ & $19.05 \pm 4.41$ & $0.000^{\star \star}$ \\
\hline AOM & $51.21 \pm 11.41$ & $50.59 \pm 6.37$ & $0.918^{\star \star}$ \\
\hline $\mathrm{AOM}+\mathrm{AvrA}$ & $83.25 \pm 4.08$ & $75.67 \pm 13.53$ & $0.265^{\star \star}$ \\
\hline $\mathrm{AOM}+$ S. typhimurium & $70.35 \pm 9.61$ & $75.96 \pm 6.32$ & $0.307^{\star \star}$ \\
\hline $\mathrm{P}$ & $0.000^{*}$ & $0.000^{*}$ & $0.000^{*}$ \\
\hline
\end{tabular}




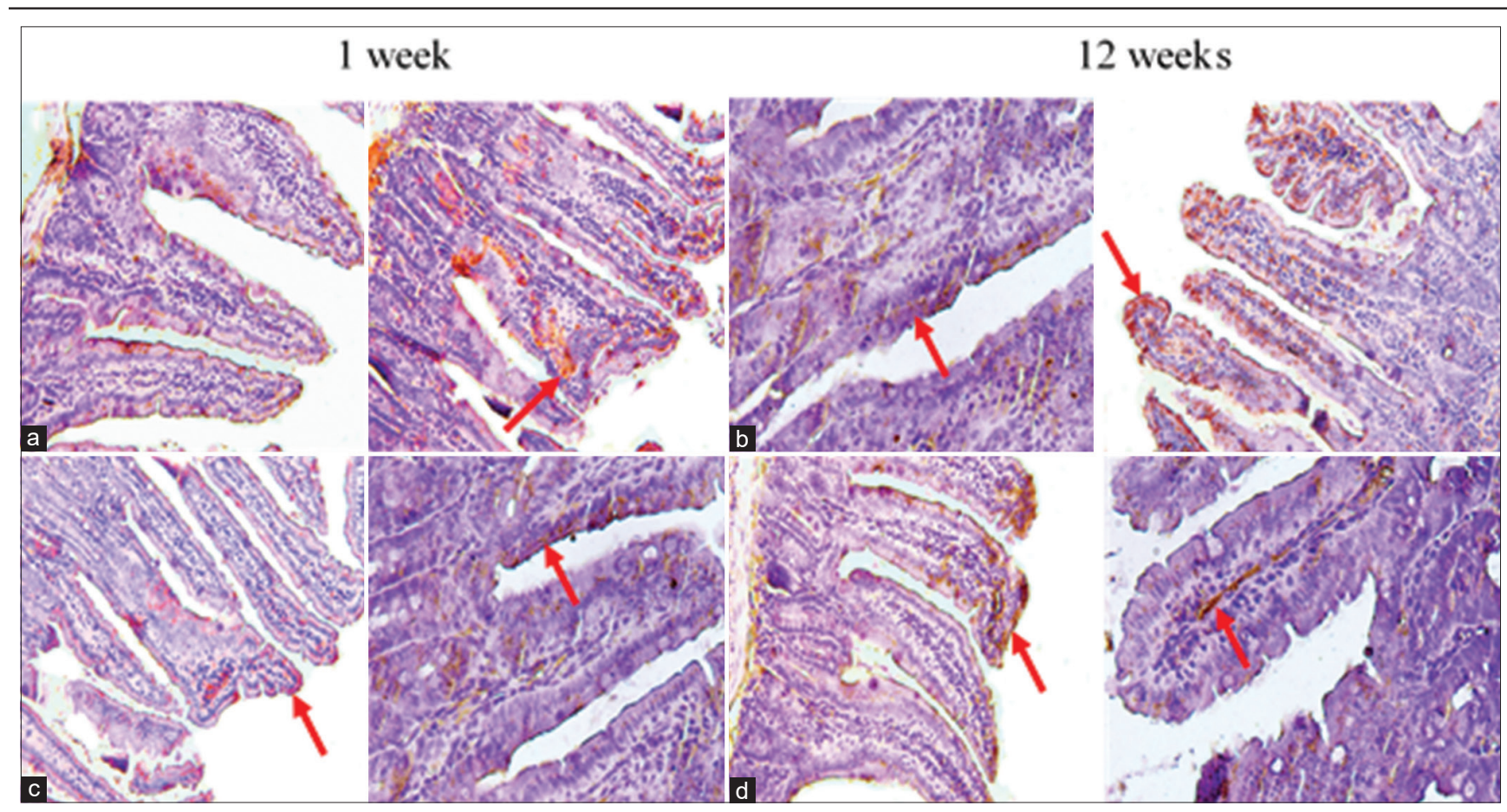

Figure 4: The effect of AvrA exposure on phosphatase and tensin homolog (PTEN) expression of the colorectal cancer model mouse. PTEN expression in colon tissue was detected by immunohistochemical staining. (a) control; (b) azoxymethane (AOM); (c) AOM + AvrA; (d) AOM + Salmonella typhimurium groups (Nikon Eclipse 100 photomicroscope with 400×)

was not significantly different. In the three treatment groups, the comparison of c-Myc expression between 1-week and 12 weeks duration showed no significant difference (Figure 7).

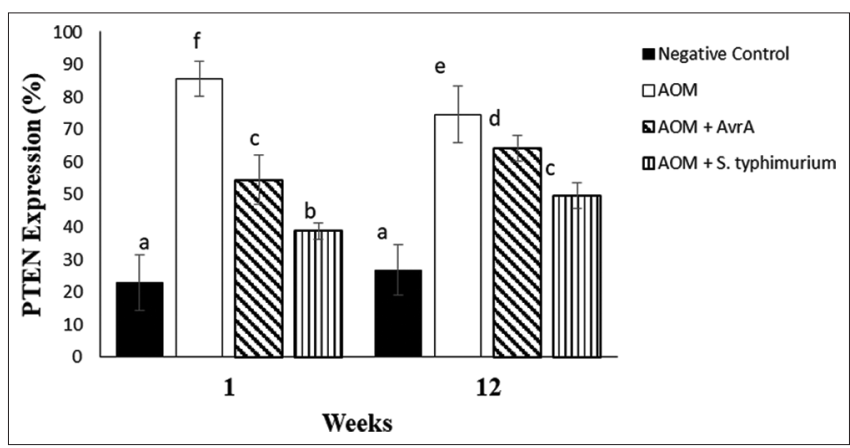

Figure 5: Comparison of phosphatase and tensin homolog expressions in the colon tissue between study groups $a, b, c, d$, e, or $f$ labels indicate that there was no significant difference between groups with the same label, as tested by multiple comparisons LSD

\section{Discussion}

Recently, growing evidence shows a correlation between Salmonella infection with the development of colon cancer [12], [13]. Inflammation is agreed on as a linking mechanism between Salmonella infection and colon cancer. However, further research identified Salmonella effector proteins which directly influence biological processes of the host [14], [15]. This study explored the effect of the Salmonella effector protein, AvrA, in inducing colon cancer in chronic and acute inflammation, using AOM -induced colorectal cancer models.
AOM is commonly used to induce colon cancer model [16]. In our study, exposure to AOM for 1 week increased ROS production in peripheral blood monocyte cells (PBMC). AOM undergoes metabolic activation into DNA-reactive products, which can alkylate macromolecules in the colon, and eventually induce DNA damage and micronucleus formation [17]. This event activates a cyclic GMP-AMP synthase - interferon gene stimulator response, which triggers transcription of inflammatory genes [18]. Immune response stimulates the production of chemokines and ROS. The immune response in the form of ROS production can be found in various peripheral mononuclear leukocytes, for example, activated monocytes [19], NK cells [20], T lymphocytes [21], and B lymphocytes [22].

The result showed that chronic exposure to AOM orally did not increase ROS production in PBMC compared with negative control, which might be attributed to adaptation of intracellular antioxidants and metabolic reprogramming [23]. Interestingly, the addition of AvrA to AOM exposure kept ROS production high in both acute and chronic treatment. Meanwhile, the combination of $S$. typhimurium and AOM increases ROS production almost double the acute treatment. These results indicate that $S$. typhimurium could stimulate acute and chronic inflammation and AvrA was one of $S$. typhimurium components that trigger inflammation.

The role of AvrA in the process of infection and inflammation might be associated with the development of colon cancer in the mouse model. In this study, AvrA exposure provided an additional inflammatory burden, which was demonstrated by higher ROS production, 


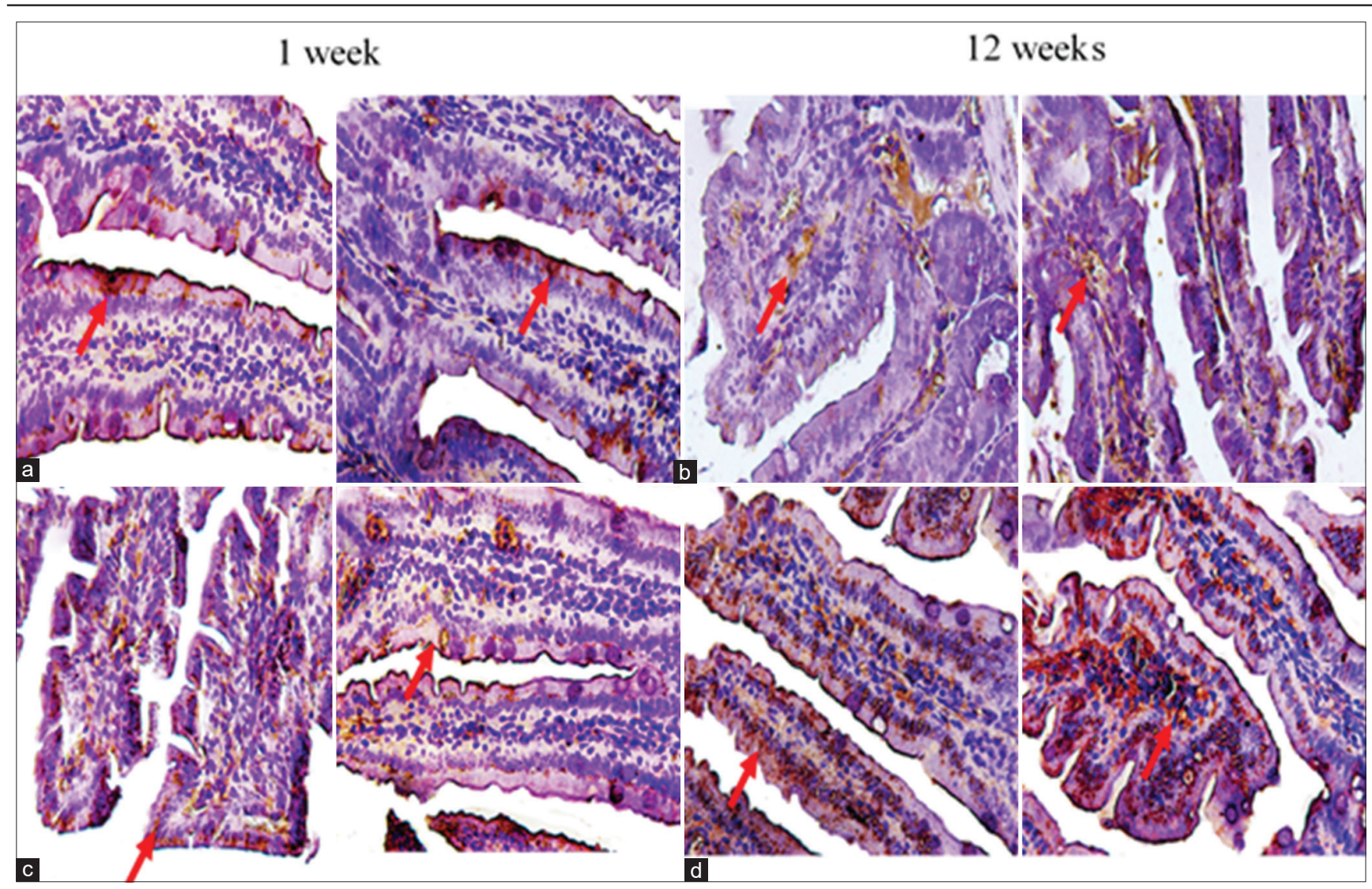

AQ3 Figure 6: Immunohistochemical results of cellular homolog expression in each group in mice model of colorectal cancer induced with azoxymethane. The decreased phosphatase and tensin homolog expression in (a) control; (b) azoxymethane (AOM); (c) AOM + AvrA; (d) AOM + Salmonella typhimurium groups (Nikon Eclipse 100 photomicroscope with 400x)

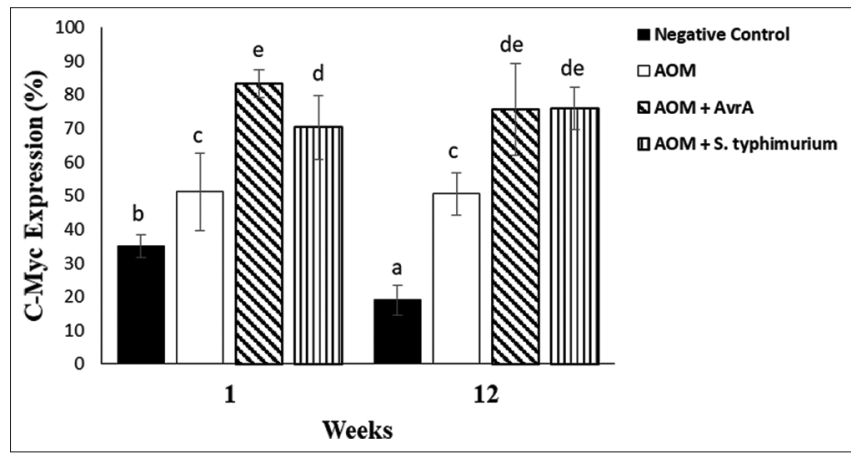

Figure 7: Comparison of cellular homolog expressions in the colon tissue between study groups $a, b, c$, $d$, or e labels indicate that there was no significant difference between groups with the same label, as tested by multiple comparisons LSD

especially in chronic exposure. ROS produced by inflammatory cells is converted to secondary products $\mathrm{O}_{2}^{-}$and $\mathrm{NO}_{2}^{-}$, as oxidizing and nitrating agents that easily damage DNA and thus accelerate mutagenesis [24]. AvrA also activates STAT3 pathways which are promoting inflammation-associated colonic tumorigenesis [25]. Inflammation activates many pathways including the NF-kB pathway that synergize with Wnt signal activation which maintains stemness and activates cancer stem cells [26], [27].

The results suggested that $A O M$ alone as well as in combination with AvrA or S. typhimurium, facilitated colorectal carcinogenesis, as observed in elevation of plasma CCA concentration after 2 weeks of the treatments. Compared to AOM exposure, AvrA exposure induced a higher concentration of CCA which supported the hypothesis that AvrA triggers colorectal carcinogenesis. However, AvrA's contribution to this process might act as the main effector protein of S. typhimurium which facilitates colorectal carcinogenesis. This notion was evidenced by the concentration of CCA in the AvrA and S. typhimurium treatments that were not significantly different.

PTEN (deleted on chromosome 10) is a negative regulator of cell growth and survival signaling pathways [28]. In this study, acute and chronic administration of AOM induced PTEN expression. AOM given by oral gavage might cause DNA damage, which, in turn, triggers increased PTEN expression as part of DNA-damage repair mechanism. In the nucleus, PTEN promotes the stability and transcriptional activity of the tumor suppressor p53 by directly associating with p53. PTEN is also found to collaborate with E2F to induce the expression of Rad51 and thus enhance DNA repair [29], [30]. PTEN also induces expression of multiple pro-apoptotic members of the Bcl2 family, stimulating expression of death receptor ligands, or by enhancing levels of various cyclin-dependent kinase inhibitors [28].

This study demonstrated that $S$. typhimurium and AvrA administration suppressed PTEN expression. 
The mechanism of decreased PTEN expression in colorectal carcinogenesis can occur epigenetically, genetically, post-translational modification, or mislocalization. Genetic mutations and a decrease in the number of PTEN gene copies are less common [31], [32].

S. typhimurium exposure caused significant suppression of PTEN compared to AvrA, which showed that AvrA had a partial role in suppressing PTEN. This result may be explained by $S$. typhimurium as a whole organism that triggers more severe inflammation [33], and the presence of other proteins, such as typhoid toxin-cytolethal distending toxin, which also affects DNA damage and carcinogenesis [34].

The results of this study suggest possible mechanism of AvrA in apoptosis and cell cycle arrest, which is in addition to its acetyltransferase activity which deactivates p53 [35], AvrA might also inhibit those events through PTEN suppression. Depression of PTEN expression will increase the activation of the phosphoinositide 3-kinase/protein phosphatase $2 A$ pathway which then activates $\beta$-catenin [36]. Besides, AvrA activates Wnt/ $\beta$-catenin pathway in intestinal stem cells through $\beta$ catenin phosphorylation (increasing activation) and deubiquitination (decreasing degradation) [37], thereby supporting the effect of Salmonella on colorectal carcinogenesis.

c-Myc gene is a proto-oncogene which produces transcription factor. c-Myc protein can activate or suppress various target genes involved in cellular function, including cell cycle, survival, protein synthesis, and cell adhesion [38]. Overexpression of $c-M y c$ was observed in $70-80 \%$ of colorectal cancers and was associated with low survival of CRC patients [39]. Increased c-Myc expression facilitates cancer characteristics development including uncontrolled proliferation, resistance to cell death, genomic instability, immune escape, angiogenesis, and metastasis [40].

The previous studies showed that exposure to AvrA-expressed Salmonella did not increase total c-Myc [41]. In contrast, our study demonstrated that exposure to isolates of AvrA protein increased $c-M y c$ expression in both acute and chronic treatment. In acute exposure, AvrA stimulated higher $c-M y c$ expression than S. typhimurium. Meanwhile, in chronic exposure, increased $c-M y c$ expression due to AvrA and S. typhimurium was comparable. This result indicates that AvrA plays a major role in increasing $c-M y c$ expression in ST-induced colorectal carcinogenesis. The elevation of c-Myc might be related to AvrA's ability to intensify $\beta$-catenin activation [37], [42]

Elevation of c-Myc expression in solid cancer occurs through various mechanisms such as gene amplification and chromosomal mutation [39], which may be related to oxidative stress and damage [43], [44]. Inflammation is another mechanism that can activate the c-Myc expression, through some inflammatory cytokine (Interleukin [IL]-6 and tumor necrosis factor- $\alpha$ ) stimulation [45]. In turn, c-Myc may stimulate the pro-inflammatory signaling pathway and cytokines, including IL-6, IL-8, IL-1 $\beta$, CCL2, and CCL20. These events provide a suitable niche for the transformation of stem cell phenotype into tumor progenitor [46]. c-Myc also contributes to maintaining self-renewal and chemoresistance properties of colon cancer stem cells [47].

\section{Conclusion}

AvrA protein effector played an important role in the inflammation - carcinogenesis sequence of colorectal. In acute and chronic Salmonella infection, AvrA had a partial role in suppressing PTEN expression and act as the main effector in regulating $\mathrm{c}-\mathrm{Myc}$ overexpression, leading to colorectal carcinogenesis. Therefore, AvrA may be a new target for the prevention and treatment of Salmonella-associated colorectal cancer.

\section{Acknowledgment}

This research was supported by the Directorate General of Higher Education Ministry of Research Technology and Higher Education, Republic Indonesia through Doctoral Scholarship Program. The authors would like to express gratitude to the Faculty of Medicine Universitas Brawijaya and Faculty of Medicine Universitas Airlangga for the research support.

\section{References}

1. Bray F, Ferlay J, Soerjomataram I, Siegel RL, Torre LA, Jemal A. Global cancer statistics 2018: GLOBOCANestimates of incidence and mortality worldwide for 36 cancers in 185 countries. CACancer J Clin. 2018;68(6):394-424. https://doi.org/10.3322/caac.21492 PMid:30207593

2. Sun J, Kato I. Gut microbiota, inflammation and colorectal cancer. Genes Dis. 2016;3(2):130-43. PMid:28078319

3. Gunn JS, Marshall JM, Baker S, Dongol S, Charles RC Ryan ET. Salmonella chronic carriage: Epidemiology, diagnosis, and gallbladder persistence. Trends Microbiol. 2014;22(11):648-55. https://doi.org/10.1016/j.tim.2014.06.007 PMid:25065707

4. Lu R, Bosland M, Xia Y, Zhang YG, Kato I, Sun J. Presence of Salmonella AvrA in colorectal tumor and its precursor lesions in mouse intestine and 
human specimens. Oncotarget. 2017;8(33):55104$15 . \quad$ https://doi.org/10.18632/oncotarget.19052 PMid:28903406

5. Mittrücker HW, Kaufmann $\mathrm{SH}$. Immune response to infection with Salmonella typhimurium in mice. J Leukoc Biol. 2000;67(4):457-63. https://doi.org/10.1002/jlb.67.4.457 PMid:10770276

6. Munro MJ, Wickremesekera SK, Peng L, Tan ST, Itinteang T. Cancer stem cells in colorectal cancer: A review. J Clin Pathol. 2018;71(2):110-6.https://doi.org/10.1136/jclinpath-2017-204739 PMid:28942428

7. CrumpJA,MintzED.Globaltrendsintyphoidandparatyphoidfever. Clin Infect Dis. 2010;50(2):241-6. https://doi.org/10.1086/649541 PMid:20014951

8. Pastille E, Bardini K, Fleissner D, Adamczyk A, Frede A, Wadwa $\mathrm{M}$, et al. Transient ablation of regulatory $\mathrm{T}$ cells improves antitumor immunity in colitis-associated colon cancer. Cancer Res. 2014;74(16):425869. https://doi.org/10.1158/0008-5472.can-13-3065 PMid:24906621

9. Wu D, Yotnda P. Production and detection of reactive oxygen species (ROS) in cancers. J Vis Exp. 2011;57:3357. PMid:22127014

10. Durban VM, Jansen M, Davies EJ, Morsink FH, Offerhaus GJ, Clarke AR. Epithelial-specific loss of PTEN results in colorectal juvenile polyp formation and invasive cancer. Am J Pathol. 2014;184(1):86-91. https://doi.org/10.1016/j.ajpath.2013.10.003 PMid:24200851

11. IwataT, Schultz D, Hicks J, Hubbard GK, Mutton LN, Lotan TL, etal. MYC overexpression induces prostatic intraepithelial neoplasia and loss of Nkx3.1 in mouse luminal epithelial cells. PLoS One. 2010;5(2):e9427. https://doi.org/10.1371/journal.pone.0009427 PMid:20195545

12. Mughini-Gras L, Schaapveld M, Kramers J, Mooij S, NeefjesBorst EA, Pelt WV, et al. Increased colon cancer risk after severe Salmonella infection. PLoS One. 2018;13(1):e0189721. https://doi.org/10.1371/journal.pone.0189721 PMid:29342165

13. Zha L, Garrett S, Sun J. Salmonella infection in chronic inflammation and gastrointestinal cancer. Diseases. 2019;7(1):28. https://doi.org/10.3390/diseases7010028 PMid:30857369

14. Haghjoo E, Galán JE. Salmonella typhi encodes a functional cytolethal distending toxin that is delivered into host cells by a bacterial-internalization pathway. Proc Natl Acad Sci USA. 2004;101(13):4614-9. https://doi.org/10.1073/pnas.0400932101 PMid:15070766

15. Liu X, Lu R, Xia Y, Wu S, Sun J. Eukaryotic signaling pathways targeted by Salmonella effector protein AvrA in intestinal infection in vivo. BMC Microbiol. 2010;10:326. PMid:21182782

16. Chen J, Huang XF. The signal pathways in azoxymethaneinduced colon cancer and preventive implications. Cancer Biol Ther. 2009;8(14):1313-7. https://doi.org/10.4161/cbt.8.14.8983 PMid:19502780

17. Yaduvanshi SK, Srivastava N, Marotta F, Jain S, Yadav $H$. Evaluation of micronuclei induction capacity and mutagenicity of organochlorine and organophosphate pesticides. Drug Metab Lett. 2012;6(3):187-97. https://doi.org/10.2174/1872312811206030006 PMid:23092307

18. Gekara NO. DNA damage-induced immune response: Micronuclei provide key platform. J Cell Biol. 2017;216(10):29993001. PMid:28860276

19. Tan HY, Wang $\mathrm{N}$, Li S, Hong $M$, Wang $X$, Feng $\mathrm{Y}$.
The reactive oxygen species in macrophage polarization: Reflecting its dual role in progression and treatment of human diseases. Oxid Med Cell Longev. 2016;2016:2795090. https://doi.org/10.1155/2016/2795090 PMid:27143992

20. Lee $\mathrm{SH}$, Almutairi S, Ali AK. Reactive oxygen species modulate immune cell effector function. J Immunol. 2017;198(1):222.20.

21. Yarosz EL, Chang $\mathrm{CH}$. The role of reactive oxygen species in regulating $\mathrm{T}$ cell-mediated immunity and disease. Immune Netw. 2018;18(1):e14. https://doi.org/10.4110/in.2018.18.e14 PMid:29503744

22. Feng $Y Y$, Tang M, Suzuki M, Gunasekara C, Anbe $Y$, Hiraoka $Y$, et al. Essential role of NADPH oxidase-dependent production of reactiveoxygenspeciesinmaintenance of sustainedBcellreceptor signaling and B cell proliferation. J Immunol. 2019;202(9):254657. https://doi.org/10.4049/jimmunol.1800443 PMid:30867238

23. Virág L, Jaén RI, Regdon Z, Boscá L, Prieto P. Selfdefense of macrophages against oxidative injury: Fighting for their own survival. Redox Biol. 2019;26:101261. https://doi.org/10.1016/j.redox.2019.101261 PMid:31279985

24. Grisham MB, Jourd'heuil D, Wink DA. Review article: Chronic inflammation and reactive oxygen and nitrogen metabolism-implications in DNA damage and mutagenesis. Aliment Pharmacol Ther. 2000;14 Suppl 1:39. https://doi.org/10.1046/j.1365-2036.2000.014s1003.x PMid:10807397

25. Lu R, Wu S, Zhang YG, Xia Y, Zhou Z, Kato I, et al Salmonella protein AvrA activates the STAT3 signaling pathway in colon cancer. Neoplasia. 2016;18(5):30716. https://doi.org/10.1016/j.neo.2016.04.001 PMid:27237322

26. Zeineldin M, Neufeld KI. New insights from animal models of colon cancer: Inflammation control as a new facet on the tumor suppressor APC gem. Gastrointest Cancer. 2015:5:39-52. https://doi.org/10.2147/gictt.s51386

27. Zhan T, Ambrosi G, Wandmacher AM, Rauscher B, Betge J, Rindtorff $\mathrm{N}$, et al. MEK inhibitors activate Wnt signalling and induce stem cell plasticity in colorectal cancer. Nat Commun. 2019;10(1):2197. https://doi.org/10.1038/s41467-019-09898-0 PMid:31097693

28. Sun $Y$, Tian $H$, Wang $L$. Effects of PTEN on the proliferation and apoptosis of colorectal cancer cells via the phosphoinositol-3-kinase/Akt pathway. Oncol Rep. 2015;33(4):1828-36. https://doi.org/10.3892/or.2015.3804 PMid:25683168

29. Chen CY, Chen J, He L, Stiles BL. PTEN: Tumor suppressor and metabolic regulator. Front Endocrinol (Lausanne). 2018;9:338. https://doi.org/10.3389/fendo.2018.00338 PMid:30038596

30. Ming $M$, He YY. PTEN in DNA damage repair. Cancer Lett. 2012;319(2):125-9. PMid:22266095

31. Salvatore L, Calegari MA, Loupakis F, Fassan M, Di Stefano B, Bensi $M$, et al. PTEN in colorectal cancer: Shedding light on its role as predictor and target. Cancers (Basel). 2019;11(11):1765. https://doi.org/10.3390/cancers 11111765 PMid:31717544

32. Kotelevets L, Scott MGH, Chastre E. Targeting PTEN in colorectal cancers. Adv Exp Med Biol. 2018;1110:55-73. PMid:30623366

33. Stecher B, Robbiani R, Walker AW, Westendorf AM, Barthel M, Kremer $M$, et al. Salmonella enterica serovar typhimurium exploits inflammation to compete with the intestinal microbiota. PLoS Biol. 2007;5(10):217789. https://doi.org/10.1371/journal.pbio.0050244 


\section{PMid:17760501}

34. Miller R, Wiedmann M. Dynamic duo-the Salmonella cytolethal distending toxin combines ADP-ribosyltransferase and nuclease activities in a novel form of the cytolethal distending toxin. Toxins (Basel). 2016;8(5):121. https://doi.org/10.3390/toxins8050121 PMid:27120620

35. Hernández-Luna M, PMuñóz-López P, Aguilar-González CA, Luria-Pérez R. Infection by Salmonella enterica promotes or demotes tumor development. In: Salmonella-A Re-Emerging Pathogen. London: Intech Open; 2018. https://doi.org/10.5772/ intechopen.75481

36. Persad A, Venkateswaran G, Hao L, Garcia ME, Yoon J, Sidhu J, etal.Active $\beta$-cateninis regulated bythePTEN/PI3kinase pathway: A role for protein phosphatase PP2A. Genes Cancer. 2016;7(1112):368-82. https://doi.org/10.18632/genesandcancer.128 PMid:28191283

37. Liu X, Lu R, Wu S, Sun J. Salmonella regulation of intestinal stem cells through the Wnt/beta-catenin pathway. FEBS Lett. 2010;584(5):911-6.https://doi.org/10.1016/j.febslet.2010.01.024 PMid:20083111

38. Dang CV, O'Donnell KA, Zeller KI, Nguyen T, Osthus RC, Li F. The C-Myc target gene network. Semin Cancer Biol. 2006;16(4):25364. $\quad$ https://doi.org/10.1016/j.semcancer.2006.07.014 PMid: 16904903

39. Lee KS, KwakY, Nam KH, Kim DW, Kang SB, Choe G, etal. c-MYC copy-number gain is an independent prognostic factor in patients with colorectal cancer. PLoS One. 2015;10(10):e0139727. https://doi.org/10.1371/journal.pone.0139727 PMid:26426996

40. Elbadawy M, Usui T, Yamawaki H, Sasaki K. Emerging roles of C-Myc in cancer stem cell-related signaling and resistance to cancer chemotherapy: A potential therapeutic target against colorectal cancer. Int J Mol Sci. 2019;20(9):2340. https://doi.org/10.3390/ijms20092340 PMid:31083525

Author Queries???

AQ3: Kindly cite figures 6 in the text part.
41. Lu R, Wu S, Zhang YG, Xia Y, Liu X, Zheng Y, et al. Enteric bacterial protein AvrA promotes colonic tumorigenesis and activates colonic beta-catenin signaling pathway. Oncogenesis. 2014;3(6):e105. https://doi.org/10.1038/oncsis.2014.20 PMid:24911876

42. Moumen M, Chiche A, Decraene C, Petit V, Gandarillas A, Deugnier MA, et al. Myc is required for $\beta$-catenin-mediated mammary stem cell amplification and tumorigenesis. Mol Cancer. 2013;12(1):132. https://doi.org/10.1186/1476-4598-12-132 PMid:24171719

43. Hunt CR, Sim JE, Sullivan SJ, Featherstone T, Golden W, Von Kapp-Herr C, et al. Genomic instability and catalase gene amplification induced by chronic exposure to oxidative stress. Cancer Res. 1998;58(17):3986-92. PMid:9731512

44. Tan SN, Sim SP, Khoo AS. Oxidative stress-induced chromosome breaks within the ABL gene: A model for chromosome rearrangement in nasopharyngeal carcinoma. Hum Genomics 2018;12(1):29. https://doi.org/10.1186/s40246-018-0160-8 PMid:29914565

45. Liu $\mathrm{H}, \mathrm{Lu}$ W, He $\mathrm{H}$, Wu J, Zhang $\mathrm{C}$, Gong $\mathrm{H}$, et al. Inflammation-dependent overexpression of c-Myc enhances CRL4 ${ }^{\text {DCAF4 }}$ E3 ligase activity and promotes ubiquitination of ST7 in colitis-associated cancer. J Pathol. 2019;248(4):464-75. $\quad$ https://doi.org/10.1002/path.5273 PMid:30945288

46. Mantovani A, Allavena P, Sica A, Balkwill F. Cancerrelated inflammation. Nature. 2008;454(7203):436$44 . \quad$ https://doi.org/10.1038/nature07205 PMid: 18650914

47. Zhang HL, Wang P, Lu MZ, Zhang SD, Zheng L. C-Myc maintains the self-renewal and chemoresistance properties of colon cancer stem cells. Oncol Lett. 2019;17(5):4487-93. https://doi.org/10.3892/ol.2019.10081 PMid:30944638 